\title{
Lectotypification of Senecio belgaumensis and S. gibsonii (Asteraceae)
}

\author{
Rajendra D. Shinde* and Rajdeo Singh \\ Blatter Herbarium, Department of Botany, St. Xavier's College (Autonomous), Mumbai -400001, \\ Maharashtra, India. \\ *E-mail: rajendra.shinde@xaviers.edu
}

\begin{abstract}
\section{Introduction}

Senecio L. (Asteraceae), a cosmopolitan genus comprises c. 1,000 species (Mabberley, 2017). In India, the genus is represented by 49 species and 6 varieties, of which 21 species are endemic (Singh et al., 2015). As a part of the taxonomic studies on the Asteraceae of Maharashtra, while studying the genus Senecio we have realized that most names of the taxa in the genus remain to be typified. In this present communication, S. belgaumensis (Wight) C.B. Clarke, an endemic to Maharashtra, Goa and Karnataka and S. gibsonii Hook.f., endemic to Maharashtra are lectotypified here as follows:
\end{abstract}

The names Senecio belgaumensis (Wight) C.B. Clarke and S. gibsonii Hook.f. are lectotypified here.

Keywords: Asteraceae, Endemic, Lectotypification, Senecio belgaumensis, Senecio gibsonii

Senecio belgaumensis (Wight) C.B. Clarke, Compos. Ind.: 200. 1876.

Madacarpus belgaumensis Wight, Calcutta J. Nat. Hist. 7(26): 157. July 1846 \& Icon. Pl. Ind. Orient. 3(4): 14, t. 1152. Sept. 1846.

Lectotype (designated here): INDIA, Karnataka: Belgaum, s.die, J.S. Law 22 (K000852219, image!).

Fig. 1

Note: Wight (1846: 157) in the protologue of $M$. belgaumensis stated "I am indebted to Mr. Law of Bombay for my specimens of this plant ...". So it is evident that Wight's description was based on more than one specimen. We found only one specimen, viz., K000852219, housed at K. The herbarium sheet has two parts of a single plant. The sheet has an annotation seemingly by Wight showing the species name, the locality Belgaum and the collector Law and his collection number. A detailed illustration of floral characters is shown on a separate sheet of paper affixed to K000852219. Since Wight's description was based on more than one specimen and K000852219 agrees with the protologue, we herewith designate K000852219 as the lectotype for the name M. belgaumensis.

Noltie (2005: 229) had mentioned "at E is a duplicate from Herb. Ind. Or. Hook.f. \& Thomson distributed from Kew under the name 'Doronicum reticulatum Wt.' with the details 'Malabar, Concan \& c... Stocks, Law, \& c.' However, the fruits are eppapose and it is therefore referable to this species; it could well be part of the same material sent by Law to Wight and therefore an isotype of Wight's species. Holotype at K: a sheet with HRWP label annotated by Wight with the name and details "Belgaum - Law no. 22."

Noltie's citation of holotype is not a correctable error because he did not indicate the holotype with the phrase "designated here".

Senecio gibsonii Hook.f., Fl. Brit. India 3: 347. 1881, 'gibsoni'.

Lectotype (designated here): INDIA, Maharashtra: Bombay, s.die, J.S. Law s.n. (K000852220, image!).

Fig. 2

Note: Hooker (1881: 347) in the protologue of $S$. gibsonii cited "The CONCAN and CANARA; Bababooden hills, Law, Dalzell." We found two relevant specimens (K000852220, K000852221) housed at K. K000852220 seemingly has two individual plants pasted in four parts, whereas K000852221 has three parts of a single or two individual plants. Both sheets show that the specimens were collected by J.S. Law from the then Bombay Presidency area (including Concan). They were originally annotated as Doronicum reticulatum Wight and belonged to the Lambert herbarium from where they were transferred 


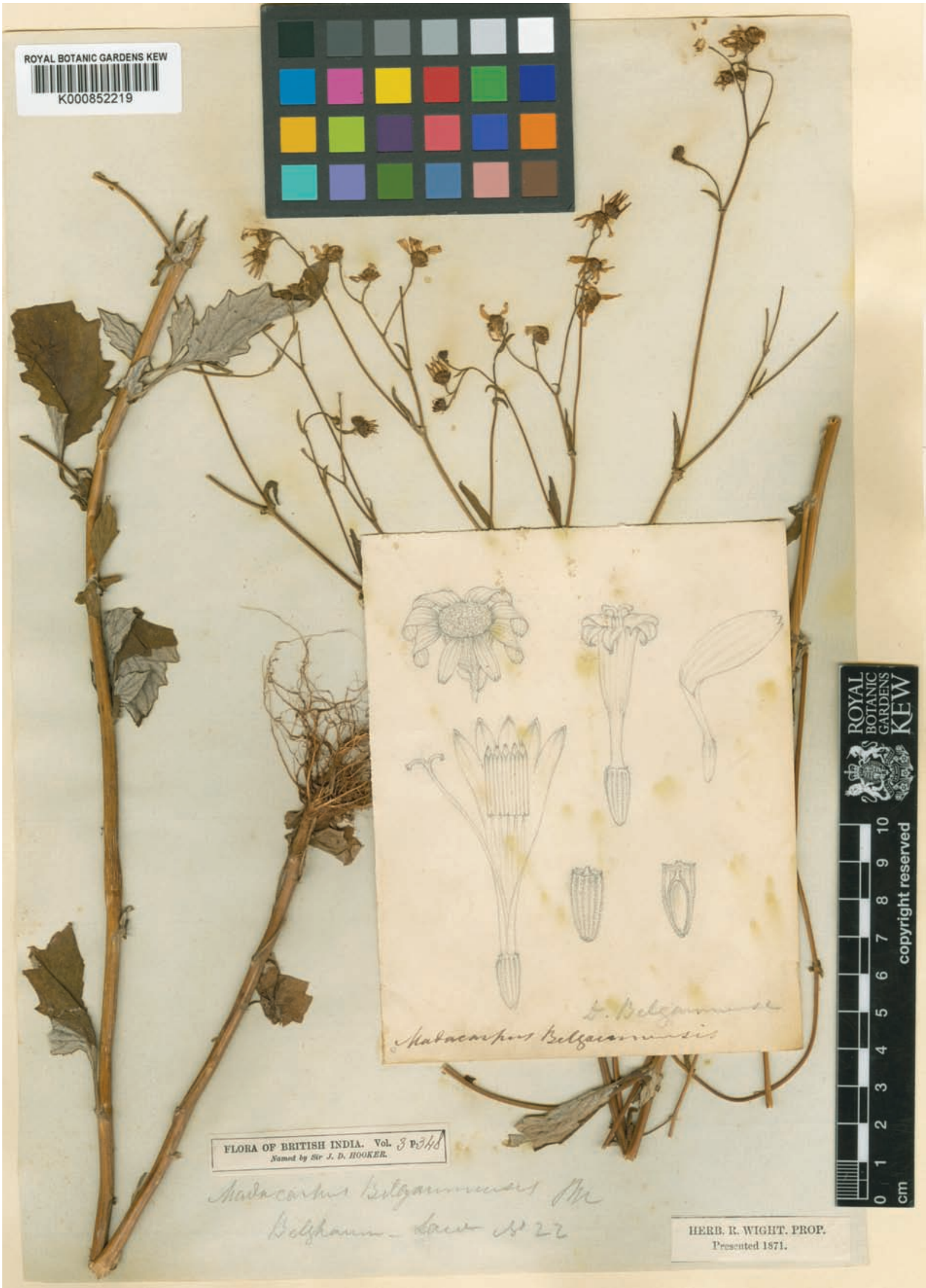

Fig. 1. Lectotype of Senecio belgaumensis (Wight) C.B. Clarke (J.S. Law 22). Reproduced with kind permission of the Board of Trustees, Royal Botanic Gardens, Kew. 


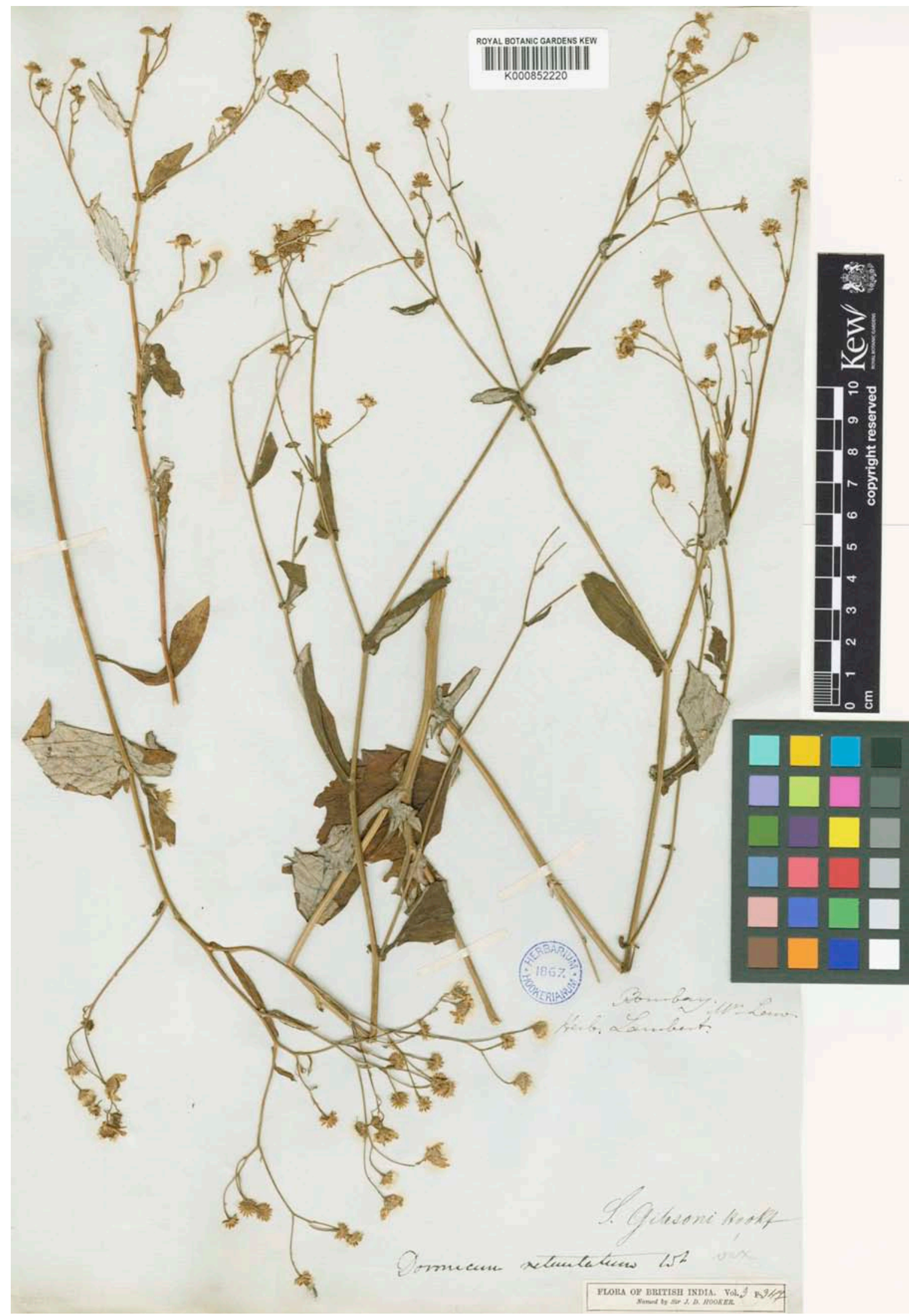

Fig. 2. Lectotype of Senecio gibsonii Hook.f. (J.S. Law s.n.). Reproduced with kind permission of the Board of Trustees, Royal Botanic Gardens, Kew. 
to Hooker's Herbarium in 1867. Of the two sheets, K000852220 the specimen with many fully bloomed inflorescences and therefore, we herewith designate K000852220 as the lectotype for the name S. gibsonii.

\section{Acknowledgements}

Authors are grateful to the Board of Trustees of Royal Botanic Gardens, Kew, for permission to publish the image of the selected lectotypes. Authors sincerely acknowledge Dr. K.N. Gandhi, Senior Nomenclatural Registrar, Harvard University Herbaria, Cambridge, for his critical comments on the typification. Authors are also thankful to the Principal, St. Xavier's College and the Director, Blatter Herbarium, for providing research facilities.

\section{Literature Cited}

Hooker, J.D. 1881. The Flora of British India. Vol. 3. L. Reeve \& Co., London.

Mabberley, D.J. 2017. Mabberley's Plant-Book: A portable dictionary of plants, their classification and uses. Fourth Edition. Cambridge University Press, Cambridge.
McNeill, J., Barrie, F.R., Buck, W.R., Demoulin, V., Greuter, W., Hawksworth, D.L., Herendeen, P.S., Knapp, S., Marhold, K., Prado, J., Prud'homme van Reine, W.F., Smith, G.F., Wiersema, J.H. \& N.J. Turland (eds.) 2012. International Code of Nomenclature for algae, fungi, and plants (Melbourne Code). Adopted by the Eighteenth International Botanical Congress Melbourne, Australia, July 2011. Regnum Veg. 154. Koeltz Scientific Books, Königstein.

Noltie, H.J. 2005. The Botany of Robert Wight. Regnum Veg. 145. A.R.G. Gantner, Ruggell.

Singh, P., Karthigeyan, K., Lakshminarasimhan, P. \& S.S. Dash 2015. Endemic vascular plants of India. Botanical Survey of India, Kolkata.

Wight, R. 1846. Notes on Indian Botany. Calcutta J. Nat. Hist. 7(26): 143-165.

Received: 1.11.2017

Revised and Accepted: 4.12.2017 